\title{
TITLE:
}

\section{AUTO-EPIZOISM IN SOUTH AFRICAN HYDROIDS}

AUTHOR(S):

Millard, Naomi A. H.

\section{CITATION:}

Millard, Naomi A. H.. AUTO-EPIZOISM IN SOUTH AFRICAN HYDROIDS.

PUBLICATIONS OF THE SETO MARINE BIOLOGICAL LABORATORY 1973, 20: $23-34$

\section{ISSUE DATE:}

1973-12-19

URL:

http://hdl.handle.net/2433/175792

RIGHT: 


\title{
AUTO-EPIZOISM IN SOUTH AFRICAN HYDROIDS
}

\author{
NAOMI A. H. MILLARD \\ South African Museum, Cape Town
}

With 6 Text-figures

\begin{abstract}
The term 'auto-epizoism' has been coined for species which live epizootically on the same or closely related species. Examples from South African Hydroida are described. In all of these some form of stunting occurs. The origin of certain obligatory epizoites can be postulated by extrapolating from the stunted form. It is suggested that this process may have evolutionary significance and present a parallel to the evolution of parasitism. Two epizootic species previously allocated to Zygophylax are transferred to Hydrodendron in the light of further knowledge, namely $H$. cornucopia and $H$. enigmatica $(=$ gracilis $)$.
\end{abstract}

It is a well-known phenomenon that certain species of hydroids live epizootically on other animals and sometimes show a marked host preference. Examples such as Hydractinia on hermit-crabs, Proboscidactyla (Lar) on tubicolous polychaets and Merona on bivalve molluses spring to mind.

There are also various small species which live epizootically on other hydroids; to mention only a few, species of Campanularia, Hebella and Filellum. Generally this is a chance association, the smaller species simply using the larger one as a favourable substratum, but occasionally there appears to be some host selection; for instance, in South Africa Campanularia laminacarpa Millard, 1966, occurs only on Thyroscyphus aequalis WARREN, 1908, and Hebella furax MiLlard, 1957, only on Plumularians, mainly Lytocarpus filamentosus (LAMARCK, 1816).

Even more interesting and curious are certain forms which are restricted to hosts of the same or closely related species. For these the term 'auto-epizoism' has been coined. Examples are found among the South African hydroid fauna and will be described in the following pages and their significance discussed.

The first three examples are species of Gymnangium (Plumulariidae, Aglaopheniinae). In all of them the normal form of the species has an erect, pinnate stem bearing a double series of hydrocladia, which in turn bear the hydrothecae. The epizootic form occurs either on the same species or on another member of the Aglaopheniinae and usually has no upright stem at all, but instead a number of solitary hydrocladia arising directly from a hydrorhiza creeping on the stem of the host. In none of these three have gonothecae been found on the epizootic form.

Gymnangium arcuatum (LAMOURoux, 1816) is a common species round the South African coast, extending from South West Africa on the west to Natal on the east, and 


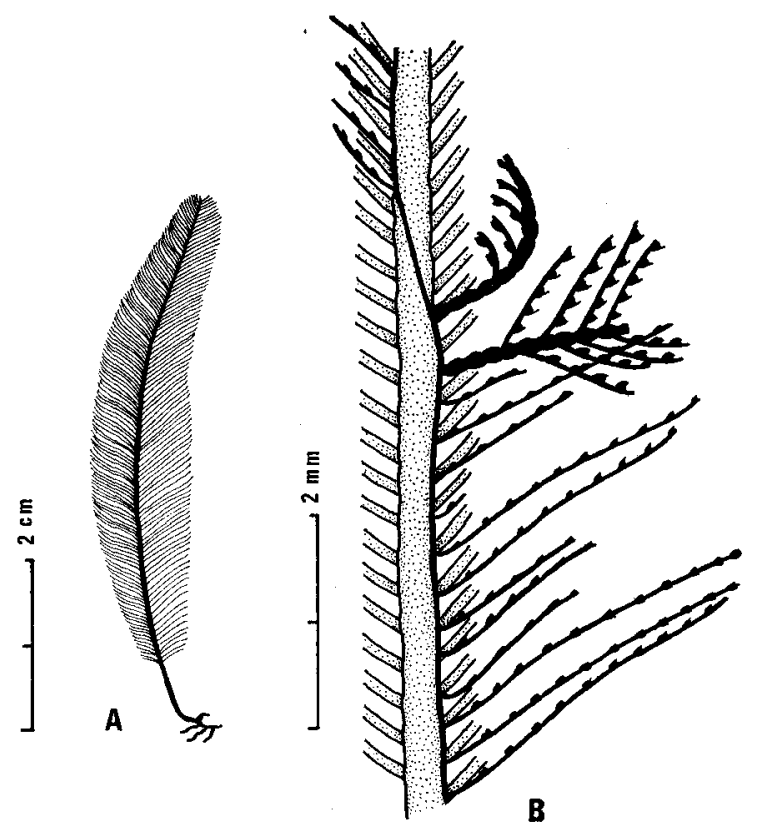

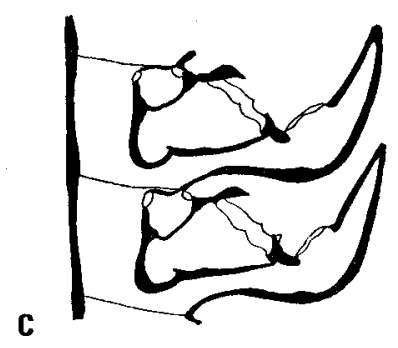

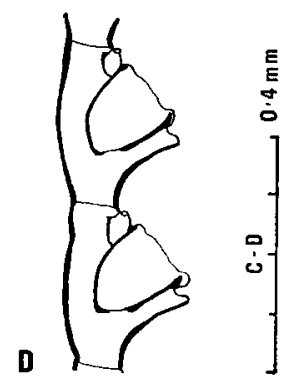

Fig. 1. Gymnangium arcuatum.

A, Normal form. B, Epizootic form growing on normal form (with hydrocladia cut short). C, Hydrothecae of normal form. D, Hydrothecae of epizootic form.

occurring from the littoral zone down to a depth of $55 \mathrm{~m}$ (Fig. 1). The pinnate stem of the normal form reaches $3-13 \mathrm{~cm}$ in height when mature. The hydrotheca has two or three pairs of lateral marginal teeth, and in addition one adcauline and one abcauline. Below it is a very large, curved, median inferior nematotheca of which the distal end may be open or closed.

The epizootic form occurs on mature stems of the same species or on Thecocarpus formosus (BUsK, 1951), which has a similar growth-form. It has not been found on any other hosts. The hydrorhiza creeps along the host stem and normally gives rise directly to solitary hydrocladia which alternate with those of the host. They are, however, much more slender (about half the diameter) and have a much paler coloration. Very rarely the epizootic colony may also produce an upright stem bearing a few hydrocladia. Such stems are always more delicate than in the normal form; the tallest one seen reached $1.3 \mathrm{~cm}$, but most are much shorter.

The epizootic hydrocladia show marked evidence of stunting. The hydrothecae are smaller than those of the normal form and the lateral and posterior marginal teeth are 'smoothed out'. The median inferior nematotheca is very much shorter and does not even reach the margin of the hydrotheca. The lateral nematothecae are also smaller and have only one aperture instead of two. These modifications are all more 
pronounced in the proximal parts of the hydrocladia.

When the epizootic form produces an upright stem, the hydrothecae, at any rate those on the distal ends of the hydrocladia, are better developed and more like those of the normal form, so that it is possible to establish the identification without any doubt.

Gymnangium africanum (MILLARD, 1958) occurs off the coast of Natal in depths of 27 to $91 \mathrm{~m}$. The pinnate stem of the normal form reaches a height of 9-16 cm. The hydrotheca differs from that of $G$. arcuatum mainly in the absence of the median adcauline marginal tooth (Fig. 2, A and B).
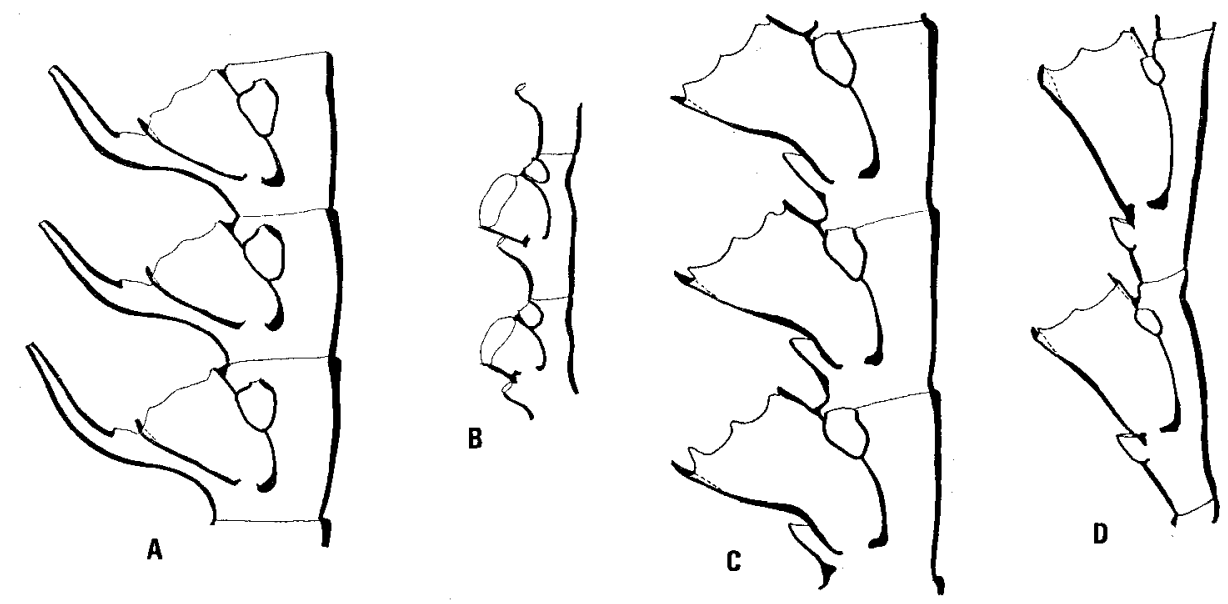

$0.5 \mathrm{~mm}$

Fig. 2. A \& B. Gymnangium africanum, hydrothecae of normal form and epizootic form, respectively.

C \& D. Gymnangium exsertum, hydrothecae of normal form and epizootic form, respectively.

The epizootic form occurs on mature stems of the same species, and so far only solitary hydrocladia have been found. These, once again, are more slender than those of the normal form (the host), the hydrotheca is very much smaller and has no marginal teeth, and the median inferior nematotheca is considerably reduced.

Gymnangium exsertum (MILlaRD, 1962) occurs on the Agulhas Bank south of the Cape Province in depths of 50 to $115 \mathrm{~m}$ (Fig. 2, C and D). The pinnate stem of the normal form reaches $6-8 \mathrm{~cm}$ in height. In this species the median inferior nematotheca is short, about one-third of the height of the hydrotheca, and the hydrotheca has a characteristic outward bend. There are three pairs of lateral marginal teeth as well as one median adcauline and one median abcauline.

The epizootic form occurs on Thecocarpus flexuosus (LAmouroux, 1816), and, as in $G$. arcuatum, consists mainly of solitary hydrocladia with, rarely, a stunted 
N. A. H. Millard

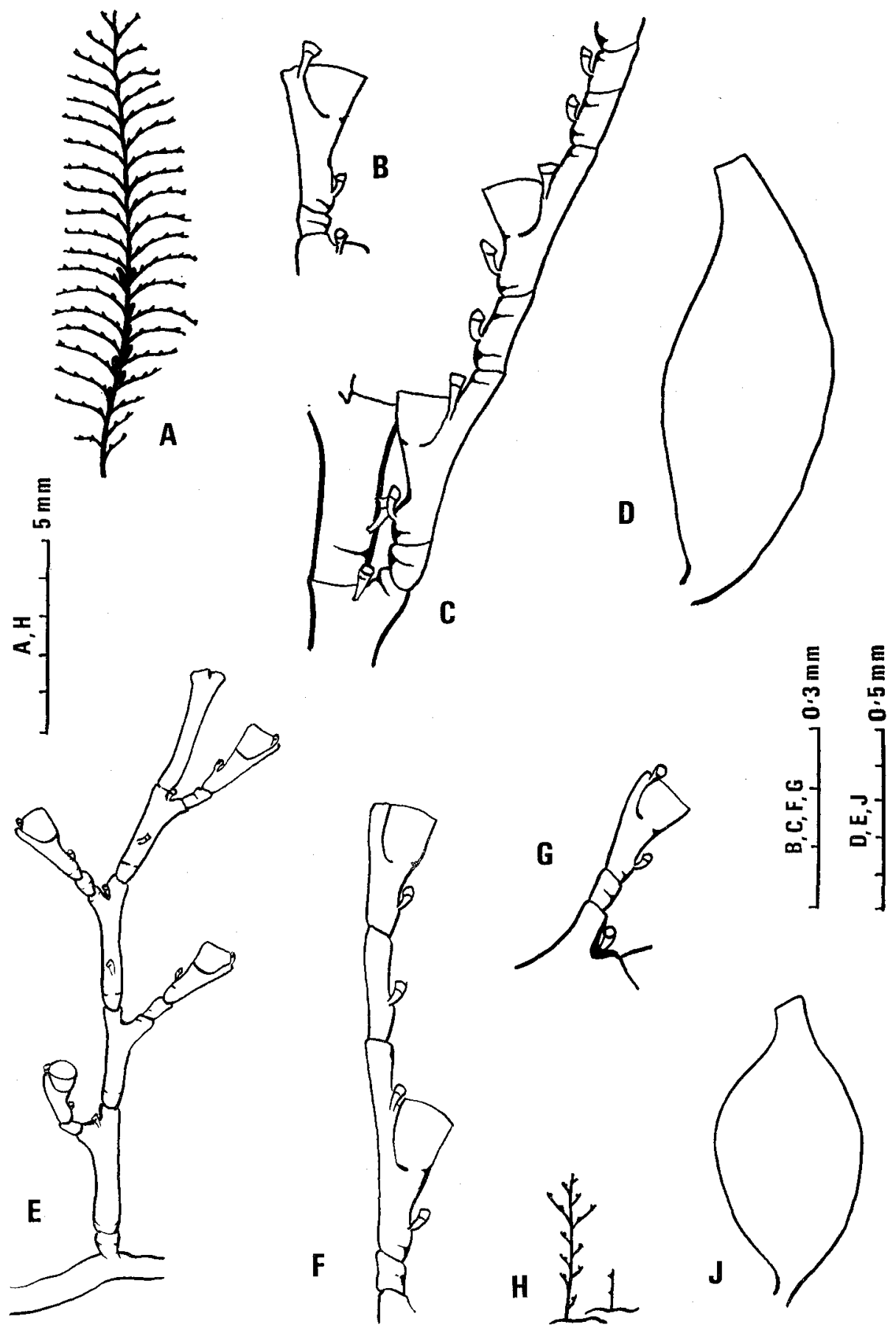

Fig. 3. Plumularia setacea.

A-D, Normal form. E-J, Epizootic form. 
pinnate stem up to $0.9 \mathrm{~cm}$ in height. Here also there is evidence of stunting, although not so marked as in the two previous species. The internodes are more slender than in the normal form, the marginal teeth of the hydrotheca are less pronounced though still recognizable and the nematothecae are smaller. The identification is established by an approach to the normal shape and size in the hydrothecae of the rare pinnate stems.

The fourth example is the well-known and cosmopolitan Plumularia setacea (Linnaeus, 1758) (Plumulariidae, Plumulariinae). It occurs all round the South African coast, from the littoral zone to $430 \mathrm{~m}$ (Fig. 3). The pinnate stem of the normal form reaches $3-4 \mathrm{~cm}$ in height; it is hardly necessary to describe it further.

An epizootic form occurs quite commonly on Nemertesia cymodocea (BusK, 1851), another member of the Plumulariinae. The hydrorhiza may give rise to solitary hydrocladia or to pinnate stems up to $0.7 \mathrm{~cm}$ in height. In the latter the hydrocladia are shorter than in the normal form and usually bear only one hydrotheca, occasionally two, and very rarely up to four. In structure the main difference from the normal form is to be found in the lateral nematothecae, which are only about half the size and barely overtop the thecal margin. In this case the identification is firmly established by the presence of gonothecae, which are typical of the species.

Among the Lafoeidae several species which normally produce erect stems may also

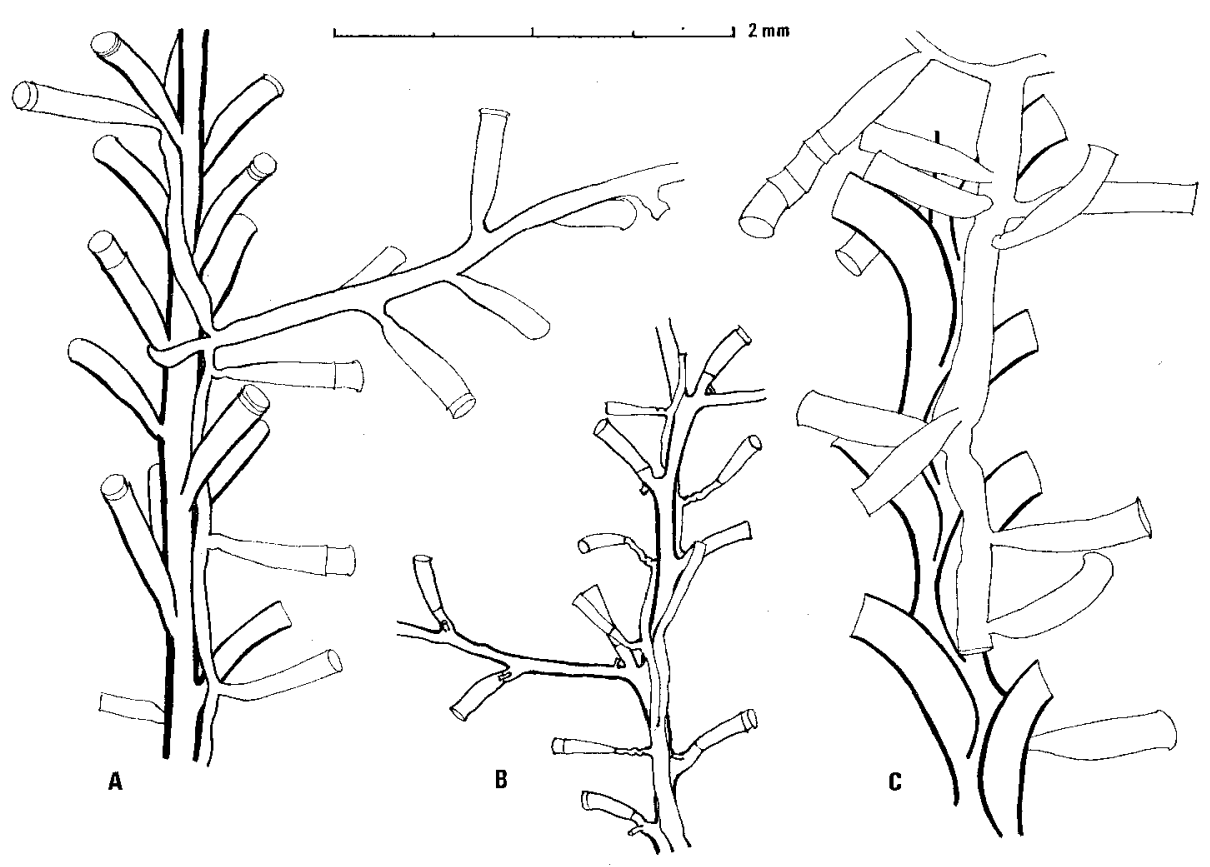

Fig. 4. Lafoeidae, part of the normal form with the auto-epizootic form growing on it, in A. Lafoea fruticosa, B. Zygophylax africana, C. Acryptolaria conferta. 
produce solitary hydrothecae. South African examples include Acryptolaria conferta (Allman, 1877), A. rectangularis (JARVIs, 1922), Cryptolaria pectinata (Allman, 1888), Lafoea fruticosa (M. SARS, 1851), Zygophylax africana STECHOw, 1923, and Z. armata (RITCHIE, 1907).

Solitary hydrothecae are typical of young colonies. It has been shown, for instance (MILLARD, 1964), that in the development of Acryptolaria conferta a solitary hydrotheca is formed first and the erect stem grows up alongside it and adnate to it.

Auto-epizootic colonies occur quite frequently in the Lafoeidae and have been observed in all the above-mentioned species (Fig. 4). Such colonies seldom progress beyond the solitary form and the hydrothecae are on the average smaller than in the normal form (Table 1).

Table 1. A comparison of hydrothecal dimensions in $\mathrm{mm}$ between the normal form and the solitary form of various Lafoeidae. Number of measurements shown in brackets.

\begin{tabular}{ccccc}
\hline Species & \multicolumn{2}{c}{ Hydrotheca, height } & Hydrotheca, marginal diameter \\
& Normal & Solitary & Normal & Solitary \\
\hline Acryptolaria conferta & $0.63-0.83$ & $0.43-0.82$ & $0.14-0.16$ & $0.12-0.15$ \\
Mean & $0.71(10)$ & $0.65(25)$ & $0.14(11)$ & $0.14(25)$ \\
\hline Acryptolaria rectangularis & $0.81-0.94$ & $0.50-0.72$ & 0.160 .19 & $0.12-0.15$ \\
Mean & $0.86(7)$ & $0.61(6)$ & $0.17(7)$ & $0.14(6)$ \\
\hline Cryptolaria pectinata & $0.28-0.35$ & $0.15-0.36$ & $0.07-0.10$ & $0.06-0.10$ \\
Mean & $0.31(16)$ & $0.24(9)$ & $0.09(16)$ & $0.08(9)$ \\
Lafoea fruticosa & $0.42-0.60$ & $0.34-0.59$ & $0.14-0.19$ & $0.10-0.14$ \\
Mean & $0.49(14)$ & $0.41(9)$ & $0.16(14)$ & $0.12(9)$ \\
\hline Zygophylax africana & $0.24-0.33$ & $0.19-0.30$ & $0.07-0.10$ & $0.06-0.10$ \\
Mean & $0.28(25)$ & $0.24(14)$ & $0.09(25)$ & $0.08(13)$ \\
\hline
\end{tabular}

It might be noted that the solitary hydrothecae of these Lafoeid species are very similar to one another and cannot be identified with certainty in the absence of an erect stem. A species such as Lafoea tenellula Allman, 1877, established on solitary hydrothecae only, cannot be regarded as valid.

To summarise to this point, auto-epizootic forms are found in certain groups of Plumulariidae and Lafoeidae and are all characterised by some degree of stunting.

Bearing in mind this stunting it may be profitable to speculate on the origin of certain species known only as epizoites.

Oswaldella nova (JARVIS, 1922) (Plumulariidae, Kirchenpaueriinae) was originally described from Zanzibar as an epizoite on Halopteris glutinosa (LAMOURoux, 1816). In South Africa it occurs fairly commonly round the coast (nine records) from the Cape Peninsula in the south to Moçambique in the east, in depths of 10 to $110 \mathrm{~m}$ (Fig. 5). It occurs only as an epizoite, and always on species of Halopterinae, namely Corhiza valdiviae (Stechow, 1923), Gattya humilis Allman, 1886, Halopteris glutinosa 

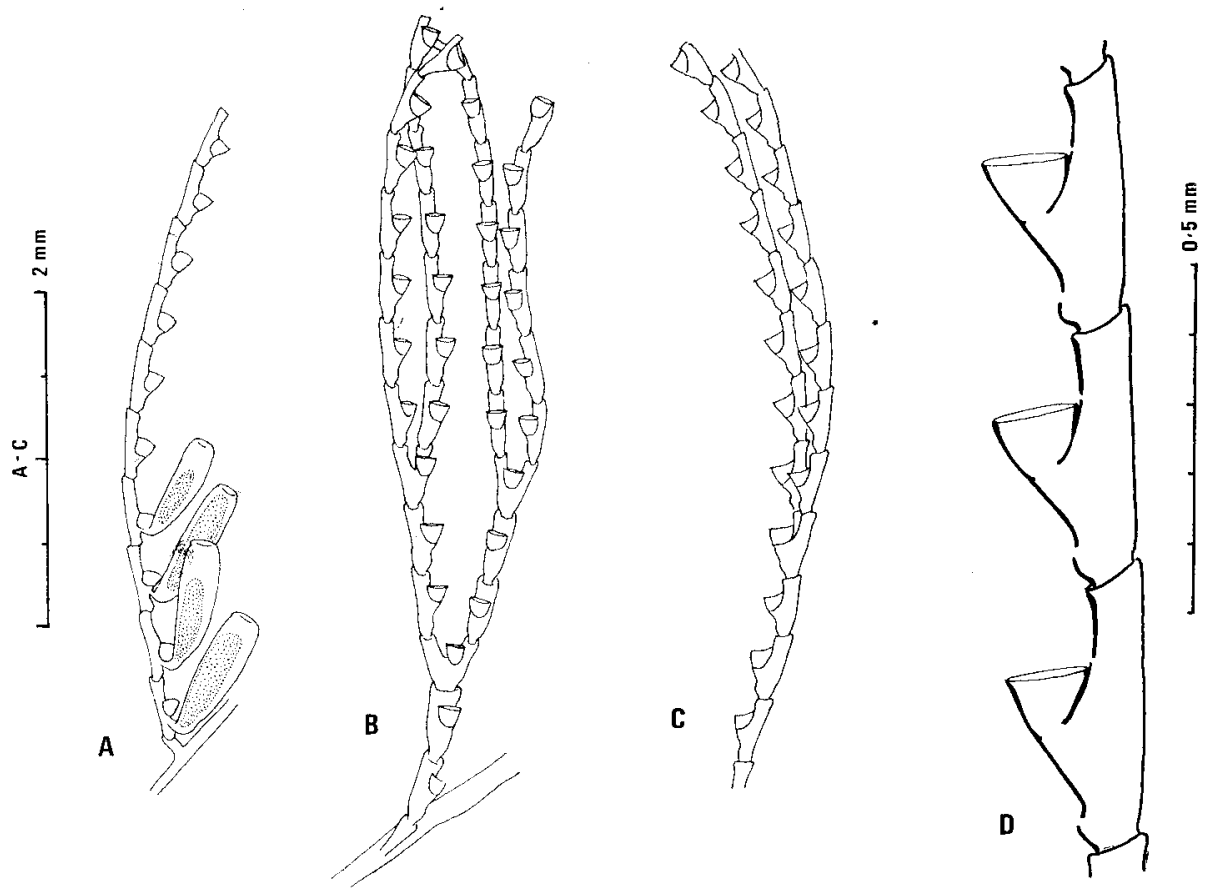

Fig. 5. Oswaldella nova. A, Unbranched hydrocladium with male gonophores.

B, Hydrocladium branching twice. C, Hydrocladium branching once. D, Details of hydrocladium.

(LAmouroux, 1816) and Halopteris polymorpha (BILlARD, 1913). In its most common form it consists of solitary hydrocladia arising directly from a hydrorhiza creeping on the host stem, but on two occasions hydrocladia have been found which are forked, either once or twice. This necessitated the transfer of the species from Kirchenpaueria to Oswaldella by MILLARD in 1962. Gonothecae, which are described here for the first time, are borne on the hydrocladia immediately below the hydrothecae. They are elongated-pear-shaped, curved at the base and truncated distally. Only the male is known.

From what we now know of the characters of epizootic forms it would be reasonable to assume that $O$. nova is the epizootic form of an Oswaldella with an erect, pinnate stem. Yet no such free-living species of the genus occurs in South Africa. The three known species of Oswaldella are all from the Antarctic, namely $O$. antarctica (JÄDERHOLM, 1904), O. bifurca (HaRtlaub, 1904) and O. billardi BriggS, 1939. These all have erect, pinnate stems bearing hydrocladia which fork, usually once in $O$. bifurca and $O$. billardi and up to three times in $O$. antarctica. $O$. billardi has a very distinctive hydrotheca which narrows distally, but in the other two species the structural details of the hydrocladia are similar to those of $O$. nova except that the dimensions are greater (Table 2). O. bifurca is the closest, since, as in $O$. nova, the hydrotheca is wider than 
Table 2. Hydrocladial measurements of Oswaldella nova in mm compared with those of $O$. bifurca and $O$. antarctica.

\begin{tabular}{|c|c|c|c|c|}
\hline & \multirow[t]{2}{*}{ O. nova } & \multirow{2}{*}{$\begin{array}{c}\text { O. bifurca } \\
\text { from TotTon, } \\
1930\end{array}$} & \multicolumn{2}{|c|}{ O. antarctica } \\
\hline & & & $\begin{array}{c}\text { from ToтToN, } \\
1930\end{array}$ & $\begin{array}{l}\text { from JäDER- } \\
\text { HOLM, } 1905\end{array}$ \\
\hline Internode, length & $0.22-0.57$ & $0.95-1.35$ & $0.63-0.75$ & \\
\hline diameter & $0.04-0.13$ & $0.13-0.18$ & $0.10-0.22$ & \\
\hline Hydrotheca, length abcauline & $0.05-0.12$ & $0.15-0.18$ & $0.20-0.26$ & $0.27-0.34$ \\
\hline diameter at margin & $0.07-0.14$ & 0.20 & $0.17-0.20$ & $0.15-0.18$ \\
\hline Gonotheca, male, length & $0.69-0.90$ & $1.54-1.83$ & & \\
\hline maximum diameter & $0.19-0.27$ & $0.51-0.59$ & & \\
\hline
\end{tabular}

deep, and the male gonotheca has a similar shape. Mature gonothecae are not known for $O$. antarctica.

Could it be that $O$. nova has evolved from an epizootic form of one of these species, which has now become specifically distinct and an obligatory epizoite?

Zygophylax cornucopia MiLlard, 1955 (Lafoeidae, but see page 33) is endemic to South Africa and occurs only as an epizoite on species of Halopterinae, namely Antennella africana Broch, 1914, A. secundaria (GMELIN, 1791), Corhiza scotiae (Ritchie, 1907), Monostaechas natalensis Millard, 1958, and M. quadridens (McCrADY, 1857). It is most common on the first of these hosts. It occurs round the South African coast from Cape Town in the south to Natal in the east, from the littoral zone to a depth of $86 \mathrm{~m}$ (Fig. 6 A-E).

The species consists of solitary hydrophores (hydrotheca + pedicel) arising directly from the hydrorhiza creeping along the stem of the host. Each hydrophore forms a cornucopia-like figure and bears a single nematotheca on the pedicel. Occasionally branching forms occur, when secondary hydrophores arise from the pedicel of the first, either unilaterally or in opposite pairs.

If one were to postulate that this is a stunted epizootic form one could speculate on the origin by extrapolating in a number of different ways.

1. By continuing the pedicel behind the hydrotheca one could produce a solitary multithecate hydrocladium (Fig. 6H), very much as occurs in the Norwegian species Ophinella parasitica (G.O. SARS, 1874). The latter species possesses hydranths too large to be contained in the hydrotheca and was included in the Haleciidae by JÄDERHOLM, 1909, but in the Plumulariidae by HincKs, 1874 and STECHOW, 1919. If the latter, which is preferable, it should belong to the subfamily Kirchenpaueriinae, for there are no lateral nematothecae and the median inferior nematotheca is small and one-chambered. This species is also an epizootic form (on Polyplumaria flabellata G.O. SARS, 1874), and might have been derived from a pinnate Kirchenpauerian.

2. By assuming that the hydrophore is a solitary hydrocladium one could create a pinnate stem bearing alternate monothecate hydrocladia (Fig. 6J), as in the South African species Zygophylax enigmatica Millard, 1964 (Fig. 6G). This species is also 

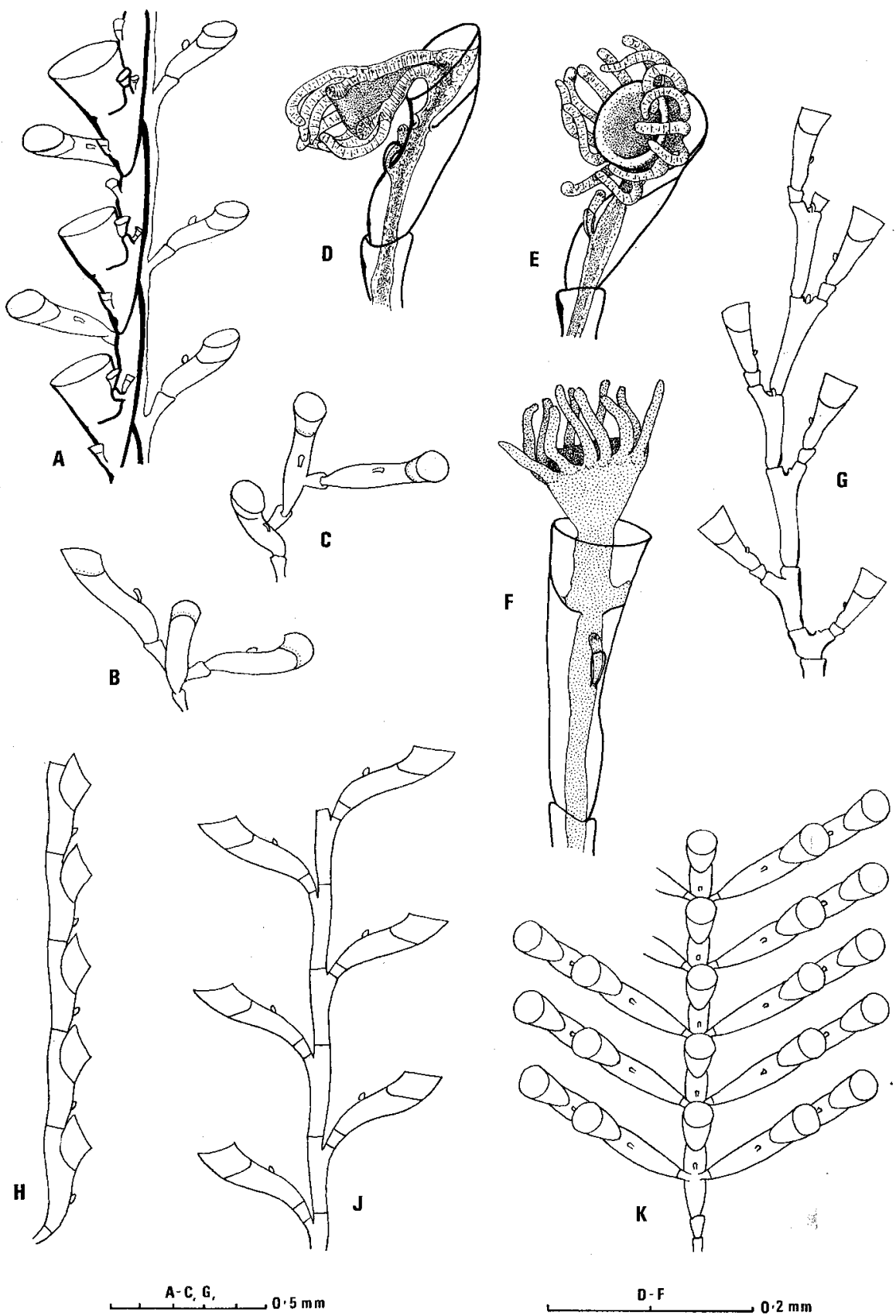

Fig. 6. A-E. Zygophylax cornucopia (=Hydrodendron cornucopia). A, Colony growing on Antennella africana. B \& C, Branching forms. D \& E, Hydrophore and hydranth in partly expanded and completely expanded state respectively. In $\mathbf{D}$ the hydranth is shown in diagrammatic half-section.

F-G. Zygophylax enigmatica (=Hydrodendron gracilis). F, Hydranth almost completely expanded. $\mathrm{G}$, Complete stem.

H-K. Hypothetical extrapolations from Zygophylax cornucopia. 
an epizoite, on Nemertesia ramosa LAMouroux, 1816, and will be discussed again below.

3. By extrapolating from the branched form and continuing the pedicels behind both the primary and secondary hydrothecae one could create a pinnate stem with cauline hydrothecae and multithecate hydrocladia (Fig. 6K), as in the genus Halopteris. This comparison is not the best one, however, for Halopteris possesses paired lateral nematothecae.

\section{Discussion}

It must be admitted freely that the ideas and extrapolations in this paper are based on preserved material only, none of the species mentioned having as yet been seen in the living form. A wide field for experimental work remains open when and if living material can be maintained in the laboratory. It would be fruitful to determine whether such forms as Oswaldella nova and Zygophylax cornucopia would produce different growth-forms if cultivated apart from the normal host, and whether the larvae of species with auto-epizootic forms have an attraction to hosts of the same or related species. Nevertheless, a certain amount of speculation may be warranted as to whether the auto-epizootic habit has any evolutionary significance. It might be tentatively suggested that larvae settling on a mature stem of the same or closely related species would be competing for similar food to the host and thus at a disadvantage. Their growth would thus be stunted, but the hydranths, being smaller, would select a smaller size-range of food and survive in this form. The question may be put as to whether, with changes in environmental conditions, the epizootic habitat could have a selective advantage to the species and eventually become genetically established. Lack of isolation would prohibit this for forms living on the same species, but might be possible for forms living on related species, particularly if controlled by a preferential attraction of the larvae to the host. It was, after all, in this sort of way that parasitism must have evolved.

\section{Remarks on the Classification of Zygophylax cornucopia and Z. enigmatica}

In the course of speculations such as the above it becomes increasingly clear that there is a very close relationship between the Plumulariidae and the nematothecabearing members of the Lafoeidae and Haleciidae, Zygophylax and Hydrodendron respectively.

The Lafoeidae are characterised by deep, tubular or bell-shaped hydrothecae, either radially symmetrical or with bilateral tendencies in forms such as Zygophylax sibogae BILlard, 1918, and Z. infundibulum Millard, 1958, where pedicel and hydrotheca together form a sigmoid or horn-shaped figure. BROCH in 1918 remarked on 
the fact that the gastral endoderm in the Lafoeidae is homogeneous and not demarcated into digestive and non-digestive regions. Several genera, including Zygophylax, typically have the gonothecae aggregated into a coppinia.

The Haleciidae have shallow hydrothecae into which the hydranth usually cannot be completely withdrawn, although in certain species of Hydrodendron the hydrotheca is deeper and can just contain the hydranth, as in H. pacifica (STECHOw, 1913). The hydrotheca is normally radially symmetrical, but occasionally shows bilateral tendencies, as in $H$. gracilis (FrASER, 1914), a good diagram of this species being given by LeLOuP, 1937, p. 17. The hydranth is very large and BROCH, 1918, has remarked that the gastral endoderm is differentiated into a proximal digestive part and a distal non-digestive part, the demarcation between the two usually being marked by a constriction. The gonothecae are not aggregated.

It is now felt that the affinities of the two species Zygophylax cornucopia and $Z$. enigmatica lie with the Haleciidae rather than the Lafoeidae and it is proposed to transfer both to the genus Hydrodendron.

Zygophylax cornucopia was originally placed in the Lafoeidae (by MILLARD, 1955) on the bilateral symmetry of the hydrotheca and pedicel, which together form a smoothrunning geometric figure resembling that found in $Z$. sibogae and $Z$. infundibulum. However, the gonothecae are solitary and are not aggregated into a coppinia. The hydranth is large and can only just be contained in the hydrotheca. Further examination shows that the gastral endoderm is demarcated into a distal region of columnar epithelium immediately below the tentacles and a proximal region of vacuolated cells (Fig. 6D). In preserved material some hydranths show a constriction between these regions, but living material has not been studied. The demarcation is not so marked as in some species of Hydrodendron and the constriction is lower in the body, yet its presence seems to preclude inclusion in the Lafoeidae. Empty hydrothecae also show a ring of refringent spots immediately above the diaphragm, as is typical of the Haleciidae. The species thus becomes Hydrodendron cornucopia (Millard, 1955).

Zygophylax enigmatica was originally placed in the Lafoeidae (by MILLARD, 1964) for similar reasons. It also has solitary gonothecae. Re-examination of the type material has revealed the presence of some cauline nematothecae (Fig. 6 F, G), and the species can now be synonymised with Ophiodes gracilis and becomes Hydrodendron gracilis (FRASER, 1914). The distribution of the species as such is the Pacific coast of North America, the West Indies, French Indo-China and South Africa. The South African material consists of a single sample from the west coast of the Cape Peninsula; it is not well-preserved, but there are indications of a differentiation in the endoderm. Though the hydranth is large, it can just be accommodated in the hydrotheca.

These two members of Hydrodendron represent Haleciidae which have achieved bilateral symmetry in the shape of the hydrophore, the oblique diaphragm and the 
definite placement of the nematotheca on one surface. From here it is but a small step to the condition found in the Plumulariidae; the growth of the pedicel behind the hydrotheca would produce a multithecate hydrocladium with the typical arrangement along one side of the axis as found in the Kirchenpaueriinae.

It must be borne in mind that if $H$. cornucopia proves to be a stunted epizootic form it may be necessary at a later stage to transfer it to the Plumulariidae.

It is thus suggested that the characters of these two species present clear evidence of the manner in which the Plumulariidae could have evolved from the Haleciidae. The Haleciidae may also have given origin to the Lafoeidae by deepening of the hydrotheca, possibly through several different and parallel lines.

\section{REFERENCES}

Broch, H. 1918. Hydroida II. Dan. Ingolf-Exped., 5 (7): 1-205.

Hincks, T. 1874. Notes on Norwegian Hydroida from deep water. Ann. Mag. nat. Hist. (4), 13: 125-137.

JÄDERHOLM, E. 1905. Hydroiden aus antarktischen und subantarktischen Meeren gesammelt von der schwedischen Südpolarexpedition. Wiss. Ergebn. schwed. Südpolar-Exped., 5: 1-41.

JäDERHOLM, E. 1909. Northern and arctic invertebrates in the collection of the Swedish State Museum (Riksmuseum). IV. Hydroiden. K. svenska VetenskAkad. Handl., 45: 1-124.

Leloup, E. 1937. Hydropolypes et Scyphopolypes recueillis par C. Dawydoff sur les côtes de l'Indochine Française. Mém. Mus, r. Hist, nat. Belg. (2), 12: 1--73.

Millard, N.A.H. 1955. New species of Hydrozoa from South Africa. Ann. S. Afr. Mus., $41: 215$ 222.

Millard, N.A.H. 1962. The Hydrozoa of the south and west coasts of South Africa. Part I. The Plumulariidae. Ann. S. Afr. Mus., 46: 261-319.

Millard, N.A.H. 1964. The Hydrozoa of the south and west coasts of South Africa. Part II. The Lafoeidae, Syntheciidae and Sertulariidae. Ann. S. Afr. Mus., 48:1-56.

Stechow, E. 1919. Zur Kenntnis der Hydroidenfauna des Mittelmeeres, Amerikas und anderer Gebiete. Zool. Jb. (System. Abt.), 42: 1-172.

Totтon, A.K. 1930. Coelenterata. Part V.-Hydroida. Nat. Hist. Rep. Br. Antarct. Terra Nova Exped.(Zool.), 5: 131-252.

\section{DISCUSSION}

BRINCKMANN-Voss: Does the auto-epizoic form settle as a larva on the host or does it grow as a "special form" from the hydrorhiza?

Millard: The planula must settle on the stem of the host, for there is no connection between the hydrorhiza of host and epizoite.

ArAI, H.: Is the epizootic mode of life genetically fixed?

MILlARD: I think that the epizootic habit has been genetically fixed in Oswaldella nova and Zygophylax cornucopia, but not in the 3 species of Gymnangium. 